\title{
Effect of apple pomace powder on the quality attributes of fish fingers.
}

\author{
Safiya Akhtar ${ }^{1}$, Murtaza Gani ${ }^{1 *}$, Hilal Ramzan Hakeem², Shaiq Ahmad Ganie ${ }^{1}$, Mir MA³, Aamir Hussain Dar ${ }^{1}$ \\ ${ }^{1}$ Department of Food Technology, IUST Awantipora, Pulwama, Kashmir, India \\ ${ }^{2}$ Department of Livestock Product Technology, R.S Pura, Jammu, India \\ ${ }^{3}$ Department of Food Technology, SKAUST, Kashmir, India
}

\begin{abstract}
The present study was undertaken to evaluate the effect of different levels of apple pomace powder (APP) on the quality characteristics of fish fingers. The apple pomace powder was incorporated at four different levels viz $0,2.5,4.5$, and 6.5 percent, replacing fish meat in the formulation. The products were analysed for various physicochemical properties, sensory attributes, emulsion stability, cooking yield, $\mathrm{pH}$ and proximate composition (viz., crude protein, fat extract, moisture content and total ash). Emulsion stability and cooking yield showed a significantly increasing trend with an increase in the level of incorporation of apple pomace powder. The $\mathrm{pH}$, crude protein, moisture, crude fat and total ash of the product showed significantly $(p \leq 0.05)$ decreasing trend with increasing levels of incorporation of apple pomace powder.
\end{abstract}

Keywords: Fish fingers, Apple pomace powder, Physico-chemical properties, Textural properties, Sensory evaluation, Refrigerated storage.

Accepted on April 16, 2019

\section{Introduction}

The worldwide demand for ready-to-eat products is constantly increasing and with today's fast pace of life, readyto-eat food has become a popular product. Consequently, fish and fish products could prove as potential sources for this kind of food. Fish represents a valuable source of dietary proteins and other nitrogenous compounds, lipids, carbohydrates, minerals and vitamins [1]. Further it is low in cholesterol, high in unsaturated fatty acids viz. omega- 3 type, which has several health benefits [2]. However, fish and fish products are considered to be poor source of dietary fibre and consumption of fibre deficient foods could possibly lead to some chronic diseases viz; obesity, cardiovascular disease, colon cancers etc. It is reported that the intake of dietary fibres could reduce the risks of these chronic disease [3,4]. Dietary fibres promote positive physiological effects to human health such as lowering of blood cholesterol and blood sugar and also reduce the digestion related disorders. Several attempts have been made to fortify the fish and fish products with dietary fibres such as wheat bran, oat fibre, barley bran etc. However, nowadays trend is to find some non-meat ingredient which could provide sufficient fibre besides possessing some anti-oxidant potential. In this regard apple pomace powder could be used as a potential source of fibre in fish products.

Apple (Malus domestica) is a typical source of dietary fibre [5]. Apple pomace is the solid phase resulting from pressing apples for juice, containing the pulp, peels and cores. It is considered as a rich source of phytochemicals and have found to have strong antioxidant activity inhibit cancer cell proliferation, decrease lipid oxidation and lower cholesterol. Being a rich source of several nutrients, apple pomace powder has been included in the formulations of several meat products. However, till now there is either very little or no documented literature regarding the usage of apple pomace powder in fish products. Therefore the present study was carried out to study the effect of different levels of apple pomace powder on physicochemical and functional properties of fish fingers and to study the shelf life studies of the developed fish fingers at refrigeration temperatures $\left(4 \pm 1^{\circ} \mathrm{C}\right)$.

\section{Material and Methods}

\section{Raw materials}

Fish meat: Fresh fish was procured from a local fish market in Sopore Baramulla and brought to the FPTC laboratory of Islamic University of Science and Technology, Awantipora for further processing. After dressing fishes were deboned by precooking method.

Apples: Apples (Malus domestica) were purchased from local fruit market of Awantipora.

Condiments: Condiments were prepared by making a fine paste of onion, ginger and garlic in the ratio of $4: 3: 1$.

Spice mixture: The various spices used in the mixture for the preparation of fish fingers were purchased from the local market and are depicted in Table 1.

Flours: Water chestnut flour was purchased from the local market of Awantipora.

Table 1. Composition of spice mixture.

\begin{tabular}{|l|c|}
\hline \multicolumn{1}{|c|}{ Spices } & Percentage (\%) \\
\hline Black cardamom (Badi elaichi) & 5 \\
\hline Cinnamon (Dalchini) & 20 \\
\hline Turmeric (Haldi) & 10 \\
\hline Clove (Loang) & 5 \\
\hline Red chilli & 10 \\
\hline Coriander (Dhania) & 20 \\
\hline Cumin (Zeera) & 10 \\
\hline Black pepper (Kalimirch) & 10 \\
\hline Aniseed (Soanf) & 10 \\
\hline Total & $\mathbf{1 0 0}$ \\
\hline
\end{tabular}


Salt: Salt (Tata) was purchased from the local market.

Packaging materials: LDPE pouches were purchased from local market of Srinagar and were used for the packaging of final product for storage studies.

\section{Methods}

Apple pomace powder preparation: After washing and coring, apples were cut into small sized pieces and ground in an electric crusher. The crushed pulp was then pressed in hydraulic press and dried in a hot air drier at $80^{\circ} \mathrm{C}$ for 2 days.

Product preparation: Four types of formulations were prepared in which the percentage of apple pomace powder varied from $0.0 \%-6.5 \%$ are presented in Table 2 .

The fish fingers were prepared using the method as described by Tokur et al. [6]. The fish samples were beheaded, gutted and washed to get their fillets. Salt and ice flakes were added to meat and minced properly in grinder for few seconds. The ingredients viz., spice mixture, condiments, flour, salt and apple pomace powder were added to the minced meat according to the formulations shown in Table 2. Weighed quantities of four types of emulsion (Control, T-1, T-2 and T-3) were taken into deep freezer for a while. After that, these were sliced and were cut into pieces to get fingers. The fish fingers were covered with breading crumbs and fried in sunflower oil at $180^{\circ} \mathrm{C}$ for 30 seconds. From each treatment sufficient quantity was utilized for sampling for physico-chemical analysis and remaining packaged in LDPE pouches and stored at $4 \pm 1^{\circ} \mathrm{C}$.

\section{Analytical procedures}

In the present study apple pomace powder was incorporated as a source of dietary fibre at four different levels i.e., control (0\%), T-1 (2.5\%), T-2 (4.5\%), and T-3 (6.5\%). All four types of products (control and treatments 1, 2 and 3) were evaluated for various parameters such as physico-chemical properties, proximate composition, texture profile analysis, sensory attributes and microbiological analysis.

\section{Physico-chemical analysis}

pH determination: The $\mathrm{pH}$ of fish finger samples soon after their preparation was determined by the method of Tokur et al. using a digital $\mathrm{pH}$ meter (Model: LABINDIA) [6]. $10 \mathrm{~g}$ of sample was blended with $50 \mathrm{ml}$ of distilled water. The $\mathrm{pH}$ of the suspension was recorded by dipping combined glass electrode of the digital $\mathrm{pH}$ meter.

Cooking yield: Cooking yield was determined by measuring weight of fish fingers for each treatments using weighing

Table 2. General formulation for the control and treatment fingers.

\begin{tabular}{|c|c|c|c|c|}
\hline Ingredients(g) & Control & T-1 & T-2 & T-3 \\
\hline Fish meat (g) & 170 & 170 & 170 & 170 \\
\hline Salt (g) & 7.5 & 7.5 & 7.5 & 7.5 \\
\hline Ice(g) & 9 & 9 & 9 & 9 \\
\hline Condiment mix. (g) & 7.5 & 7.5 & 7.5 & 7.5 \\
\hline Spice mix. (g) & 7.5 & 7.5 & 7.5 & 7.5 \\
\hline Flour (g) & 60 & 52.5 & 46.5 & 13.5 \\
\hline Apple fibre (g) & 0 & 7.5 & 13.5 & 19.5 \\
\hline
\end{tabular}

balance and calculating the ratio of cooked weight to raw weight and expressed as percentage. The weight of fish fingers was recorded before and after cooking. The cooking yield was calculated using the formula:

$$
\text { Cooking yield }(\%)=\frac{\text { Weight of cooked fish finger }}{\text { Weight of uncooked fish finger }} \times 100
$$

Proximate composition: Proximate composition in terms of moisture content, carbohydrate, ash, crude fat, crude fibre and crude protein of fish fingers were determined according to standard method of AOAC [7].

Thiobarbituric acid value: Thiobarbituric acid value of Fish fingers during storage was determined using the method of Witte et al. [8].

Texture Profile Analysis: Texture profile Analysis (TPA) of Fish fingers was conducted by the procedure forwarded by Bourne using as Instron Texture Analyser (TA.HD. Plus, Stable Micro Systems, Godalming, Surry, UK) attached to a software, texture expert [9]. Uniform-sized pieces were used as the test samples. They were placed on platform on a fixture and compressed to $50 \%$ of their original height at a cross head speed $5 \mathrm{~mm} / \mathrm{s}$ through a two cycle sequence, using a $25 \mathrm{~kg}$ load cell. The parameters determined were: Hardness ( $\mathrm{kg}$ ):Peak force/ energy required to compress the sample; Adhesiveness $(\mathrm{kg})$ : Negative area under baseline between the compression cycles or A3; Cohesiveness :extent to which sample could be deformed prior to rupture (A2/A1,A1 being the maximum force required for the first compression and A2 being the maximum force required for second compression); Springness ( $\mathrm{mm})$ :height that sample recovers during the time elapses between end of the first compression, i.e., ability of sample to recover its original height after the deforming force was removed; Gumminess(mm): (hardness $\times$ cohesiveness); Chewiness $(\mathrm{kg})$ : (Springness $\times$ gumminess).

Sensory evaluation: The sensory attributes, namely appearance and colour, flavour, taste, texture and overall acceptability, were evaluated using 5 point hedonic scale where 5=excellent, 4=good, 3=fair, 2=acceptable, 1=not acceptable [10]. The fried fingers were served to 7 member panel of faculty members of Food Science and Technology, Islamic University of Science and Technology, Awantipora to determine their sensory characteristics. Coded samples were served randomly to the panellists. The nature of experiment was explained to the panellists without disclosing the identity of samples. Water was provided to rinse the mouth between the samples. The panellists judged the samples for appearance, flavour, texture, colour and taste.

Colour measurement: Colour measurements were performed on fish fingers by using Hunter colour Lab. The apparatus was standardized before measuring the samples. Hunter L*(lightness), a*(redness/greenness) and b*(yellowness/ blueness) values of fish fingers were measured. Three samples for each formulation were analysed and the average value was determined by taking the observations from three different locations on a given sample. 


\section{Microbiological evaluation}

Total plate count, yeast and mould count of the samples were determined by standard method [11]. Glassware was autoclaved at $121{ }^{\circ} \mathrm{C}$ for 15 minutes in MAC Autoclave Vertical (Model: Narang scientific Works, PVT LTD, New Delhi). Preparation of samples and serial dilutions were done near the flame in a horizontal laminar flow cabinet (Model: Narang Scientific Works, PVT LTD, Delhi-202) which was pre-sterilised by ultraviolet irradiation observing all possible aseptic conditions.

Preparation of homogenate: About $10 \mathrm{~g}$ of the sample was blended with app. volume of the diluent (sterile $0.1 \%$ peptone water) and homogenized in a vortex (Model: SPINIX) for 30-60 seconds.

Preparation of serial dilution: For serial dilution $1 \mathrm{ml}$ of sample homogenate was transferred into a tube containing $9 \mathrm{ml}$ of diluent with the help of a pipette for first dilution $\left(10^{-1}\right)$. For second dilution $\left(10^{-2}\right) 1 \mathrm{ml}$ was transferred from the first dilution to second tube containing $9 \mathrm{ml}$ of sterile $0.1 \%$ peptone water. $1 \mathrm{ml}$ of this solution was transferred to another tube for third $\left(10^{-3}\right)$ dilution. The procedure was repeated until the desired solution was obtained.

Total plate count: About 28g of nutrient agar was dissolved in $1000 \mathrm{ml}$ distilled water and autoclaved before plating. About 15$20 \mathrm{ml}$ of sterilized media was mixed thoroughly. $1 \mathrm{ml}$ inoculum each from $10^{-1}, 10^{-2}, 10^{-3}$ and $10^{-4}$ dilutions was inoculated into already sterilized petriplates into which nutrient agar had been poured. Plates were incubated inverted in B.O.D incubator (Model : Caltan Super Deluxe Automatic, Narang Scientific Works, Pvt. Ltd., New Delhi-152) at $35^{\circ} \mathrm{C}$ for $24-48$ hours. Cfu/g was calculated by taking average number of colonies which was multiplied by reciprocal of dilution factor and expressed as log cfu/g.

Yeast and mould count: Potato Dextrose Agar was used for enumeration of yeast and mould count. $39 \mathrm{~g}$ of potato dextrose agar (PDA) was added in 1 litre of distilled water and autoclaved. The media was poured into petriplates and allowed to solidify. After inoculation the petriplates were incubated at $25^{\circ} \mathrm{C}$ for 24-48 hours. Yeasts appeared as blue green or white in colour and formed small defined colonies. Mould colonies were blue and tend to be larger than yeast colonies. Yeast and mould count were calculated by multiplying total number of yeast and mould count colonies/plates by appropriate dilution factor and expressed as $\log \mathrm{cfu} / \mathrm{g}$.

\section{Statistical analysis}

The statistical design was 4 (treatments) $\times 3$ (replication) randomized block design. The data generated was compiled and analysed following the Standard procedure, for the analysis of variance (ANOVA) and Duncan's test (at 5\% significance level) using Minitab 16 for comparing the mean values to find the effect of treatments, storage periods and their interactions for various parameters in different experiments [12].

\section{Results and Discussion}

\section{Proximate composition of raw meat}

The $\mathrm{pH}$ and proximate composition of fresh fish flesh is presented in Table 3. The results are in agreement to that previously reported by Levent ICZI in fish meat [13]. Proximate analysis showed that control had higher moisture content than apple pomace powder incorporated samples. The moisture content of treatments decreased with increase in concentration of apple pomace powder. This decrease in moisture content could be due to the lower moisture content of apple pomace powder. The results are contradictory with the finding of Verma et al., [14] who reported a gradual increase in the moisture of emulsion with increase in replacement level of guava powder in sheep meat nugget. The fat content of fish fingers is significantly ( $\mathrm{p} \leq 0.05)$ higher than $\mathrm{T}_{1}(2.5 \%), \mathrm{T}_{2}(4.5 \%)$ and $\mathrm{T}_{3}(6.5 \%)$. Among the treatment fat content of $\mathrm{T}_{3}(6.5 \%)$ was significantly $(\mathrm{p} \leq 0.05)$ lower than $\mathrm{T}_{1}(5 \%)$ and $\mathrm{T}_{2}(10 \%)$ respectively. This decrease in fat content could be attributed to the increase in the level of apple pomace powder. These findings are in agreement with those reported by Huda et al. [15]. Garcia et al. [16] also reported decrease in fat content of dry fermented sausages with the addition of orange, apple and peach fibres. The mean values of total ash showed a significantly decreasing trend with increase in the level of apple pomace powder. This decrease in total ash content could be attributed to lower ash content in apple pomace powder. These findings are in agreement with the finding of Mendoza et al. [17] who observed similar trend in cow fat dry fermented sausage incorporated with inulin as fat substitute. The protein content of control was found to be significantly ( $\mathrm{p}$ $\leq 0.05)$ higher than $\mathrm{T}_{1}(2.5 \%), \mathrm{T}_{2}(4.5 \%)$ and $\mathrm{T}_{3}(6.5 \%)$. Among the treatments protein content decreased significantly $(\mathrm{p} \leq 0.05)$ with the increasing levels of apple pomace powder. This was in accordance with the investigations of Huda et al. [15] who found that the addition of apple pomace reduced the protein content of mutton nuggets. Alonso et al. [18] also reported that protein percent of fish muscle with the incorporation of grape dietary fibre decreased with the increase in the levels of GADF. The crude fibre values showed a significantly $(\mathrm{p} \leq 0.05)$ increasing trend with increase in the level of incorporation of apple pomace powder. The significant increase in crude fibre values could be possibly due to the higher fibre content of apple fibre. Huda et al. observed similar increase in the crude fibre in apple pomace incorporated mutton nuggets [15]. FernandezGines et al. [19] reported that the utilization of lemon albedo, a major component of lemon peel as a source of dietary fibre increased the fibre content in bologna sausages.

\section{Effect of apple pomace powder on the physico-chemical properties of fish fingers}

The results of $\mathrm{pH}$, emulsion stability and cooking yield of developed fish fingers with $0,2.5 \%, 4.5 \%$ and $6.5 \%$ apple

Table 3. pH and proximate composition (\%) of raw fish flesh.

\begin{tabular}{|c|c|}
\hline Parameters & Value \\
\hline Moisture (\%) & $76.20 \pm 0.05^{\mathrm{a}}$ \\
\hline Ash (\%) & $1.54 \pm 0.02^{\mathrm{e}}$ \\
\hline Crude fat (\%) & $2.53 \pm 0.03^{\mathrm{d}}$ \\
\hline Crude protein (\%) & $17.25 \pm 0.03^{\mathrm{b}}$ \\
\hline $\mathrm{pH}$ & $6.22 \pm 0.11^{\mathrm{c}}$ \\
\hline
\end{tabular}

All values are average of three determinations $(n=3)$ 
Table 4. Effect of apple pomace powder on the physico-chemical properties of fish fingers.

\begin{tabular}{|l|c|c|c|c|}
\hline \multicolumn{1}{|c|}{ Parameters } & Control & $\mathbf{T}_{1}$ & $\mathbf{T}_{2}$ & $\mathbf{T}_{3}$ \\
\hline pH & $6.39 \pm 0.68^{\mathrm{a}}$ & $6.18 \pm 0.05^{\mathrm{b}}$ & $5.96 \pm 0.03^{\mathrm{c}}$ & $5.84 \pm 0.07^{\mathrm{c}}$ \\
\hline Emulsion stability (\%) & $89.17 \pm 0.03^{\mathrm{a}}$ & $89.90 \pm 0.02^{\mathrm{b}}$ & $90.25 \pm 0.02^{\mathrm{c}}$ & $91.65 \pm 0.04^{\mathrm{c}}$ \\
\hline Cooking yield (\%) & $91.21 \pm 0.05^{\mathrm{a}}$ & $91.74 \pm 0.11^{\mathrm{b}}$ & $91.97 \pm 0.03^{\mathrm{c}}$ & $92.11 \pm 0.10^{\mathrm{d}}$ \\
\hline
\end{tabular}

All values are average of three determinations $(n=3)$

Row-wise values bearing different superscripts (small) differ significantly $(p \leq 0.05)$ Control: fish fingers with APP (0\%)

T1: Fish fingers with $A P P(2.5 \%)$

T2: Fish fingers with APP (4.5\%)

T3: Fish fingers with APP (6.5\%)

pomace powder are depicted in Table 4.

\section{$p H$}

The $\mathrm{pH}$ values for control and apple pomace powder incorporated fish fingers are reported in Table 4. Results revealed that $\mathrm{pH}$ values showed a declining trend with the increase in the level of apple fibre incorporated. This decrease in $\mathrm{pH}$ could be attributed to the mild sourness in apple fibre. Decrease in $\mathrm{pH}$ scores are consistent with the findings of Cadun et al. [20] who reported that the effect of fibres on the quality of fish patties stored at $\left(0-4^{\circ} \mathrm{C}\right)$ resulted in gradual decrease in $\mathrm{pH}$ as the apple fibre was added. Verma et al. [21] reported that addition of apple pulp in low fat chicken nuggets resulted in gradual decrease in product $\mathrm{pH}$ as the level of apple pulp increased. The $\mathrm{pH}$ results of the present study are in consonance with the finding of Verma et al., who also reported a decrease in $\mathrm{pH}$ value of sheep meat nuggets incorporated with guava powder [21].

\section{Emulsion stability}

The emulsion stability increased significantly with the increase in the level of apple pomace powder. The possible reasons for the increase in the emulsion stability due to the apple pomace powder inclusion could be attributed to linear decrease in $\mathrm{pH}$. These findings are in agreement with those reported by Choi et al., who reported that emulsion stability improved in meat products incorporated with dietary fibre [22]. Similar results were also reported by Fernandez-Gines et al. in bologna sausage containing different concentrations of orange fibre [19].

\section{Cooking yield}

The results of cooking determinants indicated that the control had significantly $(\mathrm{p} \geq 0.05)$ lower cooking yield than $\mathrm{T}_{1}$ $(2.5 \%), \mathrm{T}_{2}(4.5 \%)$ and $\mathrm{T}_{3}(6.5 \%)$. Among the treatment groups cooking yield increased significantly $(\mathrm{p} \leq 0.05)$ with increasing levels of apple pomace powder as shown in Table 4. Alonso et al., [18] reported that the addition of fibre increased the cooking yield in minced fish muscle. Similar findings were documented by Huda et al., [15] in mutton nuggets. Besbes et al. [23] also reported that the use of dietary fibres from pea and wheat as a meat replacement in beef burger patties increases cooking yield but decreased shrinkage. The results are also in agreement with those reported by Mitsyk and Mikhailovskii [24].

\section{Proximate composition of fish finger}

The proximate composition (moisture, carbohydrate, total ash, crude fibre, crude fat and protein) of fish fingers is shown in Table 5.

\section{Sensory attributes of fish fingers}

The results for sensory evaluation of fish fingers incorporated with apple pomace powder i.e., appearance, colour, flavour, juiciness, and texture is presented in Table 6. Incorporation of fish fingers with apple pomace powder had a significant effect on the most of the sensory attributes. Incorporation of fingers with apple pomace powder showed a significantly $(p \leq 0.05)$ decreasing trend with increase in the level of apple pomace powder. Appearance, colour and juiciness showed similar patterns. However, flavour showed significant effect at all levels of incorporation. The significant effect was observed beyond $4.5 \%$ level of incorporation. Similar results have been reported by Huda et al. for mutton nuggets [15].

\section{Texture profile analysis}

The Textural properties of fish fingers were evaluated using an Instron Texture analyser (TA.HD. Plus, Stable Micro Systems, Godalming, Surrey, UK) at the department of Food Technology, Awantipora. Force-by -time data from each test were used to calculate mean values for the TPA parameters of each treatment. Results of the Texture profile analysis of control and treatments are shown in Table 7. The hardness, gumminess and chewiness value of control was significantly ( $p$ $\geq 0.05$ ) lower as compared to treatments with different levels of apple pomace powder. High moisture retention might also be responsible for decrease in hardness among the treatments.

Table 5: Effect of Apple pomace powder on the proximate composition of fish fingers.

\begin{tabular}{|l|c|c|c|c|}
\hline \multicolumn{1}{|c|}{ Parameters } & Control & $\mathbf{T}_{1}$ & $\mathbf{T}_{2}$ & $\mathbf{T}_{3}$ \\
\hline Moisture (\%) & $67.28 \pm 0.03^{\mathrm{a}}$ & $66.92 \pm 0.26^{\mathrm{b}}$ & $66.44 \pm 0.03^{\mathrm{c}}$ & $66.02 \pm 0.01^{\mathrm{d}}$ \\
\hline Crude protein (\%) & $18.08 \pm 0.02^{\mathrm{a}}$ & $17.46 \pm 0.02^{\mathrm{b}}$ & $16.89 \pm 0.05^{\mathrm{c}}$ & $16.30 \pm 0.02^{\mathrm{d}}$ \\
\hline Crude fat (\%) & $8.90 \pm 0.01^{\mathrm{a}}$ & $8.08 \pm 0.00^{\mathrm{b}}$ & $7.38 \pm 0.05^{\mathrm{b}}$ & $7.05 \pm 0.03^{\mathrm{c}}$ \\
\hline Ash (\%) & $2.43 \pm 0.04^{\mathrm{a}}$ & $2.29 \pm 0.02^{\mathrm{ab}}$ & $2.24 \pm 0.06^{\mathrm{b}}$ & $2.15 \pm 0.06^{\mathrm{b}}$ \\
\hline Crude Fibre (\%) & $0.42 \pm 0.04^{\mathrm{a}}$ & $1.66 \pm 0.04^{\mathrm{b}}$ & $2.58 \pm 0.08^{\mathrm{c}}$ & $3.27 \pm 0.02^{\mathrm{d}}$ \\
\hline
\end{tabular}

All values are average of three determinations $(n=3)$

Row wise mean values bearing different superscripts (small) differ significantly ( $p$ $\leq$ 0.05)

Control fish fingers with APP (0\%)

T1: Fish fingers with APP (2.5\%)

T2: Fish fingers with APP (4.5\%)

T3: Fish fingers with APP (6.5\%)

Table 6. Effect of apple pomace powder on the sensory properties of fish fingers.

\begin{tabular}{|l|c|c|c|c|}
\hline \multicolumn{1}{|c|}{ Parameters } & Control & $\mathbf{T}_{1}$ & $\mathbf{T}_{2}$ & $\mathbf{T}_{3}$ \\
\hline Appearance & $4.68 \pm 0.00^{\mathrm{a}}$ & $4.55 \pm 0.30^{\mathrm{a}}$ & $3.86 \pm 0.86^{\mathrm{b}}$ & $3.66 \pm 0.20^{\mathrm{c}}$ \\
\hline Colour & $4.51 \pm 0.25^{\mathrm{a}}$ & $4.36 \pm 0.29^{\mathrm{a}}$ & $3.98 \pm 0.25^{\mathrm{b}}$ & $3.63 \pm 0.22^{\mathrm{c}}$ \\
\hline Juiciness & $4.30 \pm 0.31^{\mathrm{a}}$ & $4.17 \pm 0.31^{\mathrm{ab}}$ & $3.98 \pm 0.25^{\mathrm{bc}}$ & $3.88 \pm 0.22^{\mathrm{c}}$ \\
\hline Flavour & $4.39 \pm 0.30^{\mathrm{a}}$ & $4.39 \pm 0.36^{\mathrm{a}}$ & $3.73 \pm 0.29^{\mathrm{b}}$ & $3.57 \pm 0.23^{\mathrm{b}}$ \\
\hline Texture & $4.26 \pm 0.29^{\mathrm{a}}$ & $4.20 \pm 0.35^{\mathrm{a}}$ & $3.98 \pm 0.31^{\mathrm{b}}$ & $3.57 \pm 0.25^{\mathrm{b}}$ \\
\hline
\end{tabular}

All values are average of fifteen determinations $(n=21)$

Row-wise mean values bearing different superscripts (small) differ significantly ( $p$ $\leq 0.05)$

Control: Fish fingers with APP (0\%)

T1: Fish fingers with APP (2.5\%)

T2: Fish fingers with APP (4.5\%)

T3: Fish fingers with APP (6.5\%) 
Similar results were also reported by Cadun et al. [20]. Control group had significantly $(\mathrm{p} \leq 0.05)$ higher cohesiveness value in comparison to treatment groups. Huda et al. observed the same trend in mutton nuggets by incorporating apple pomace [25]. Mendoza et al. reported that inclusion of dietary inulin in low fat sausage resulted in decreased cohesiveness [17]. Chewiness values of control were significantly higher $(\mathrm{p} \leq 0.05)$ than treatments. Fish fingers prepared with $2.5 \%, 4.5 \%$ and $6.5 \%$ apple pomace powder were less chewy than control. Lin and Lin also reported decrease in chewiness values of Chinese style meat balls containing bacterial cellulose (Natta) [26].

\section{Storage studies}

Colour analysis: The changes in colour parameters during storage period were given in Table 8 . $\mathrm{L}^{*}$ (lightness) and $\mathrm{b}^{*}$ (yellowness) values of fish fingers with apple pomace powder were significantly higher than the values of control during the storage period $(\mathrm{p}<0.05)$. Cadun et al. reported that the addition of apple fibre increased the $L$ and $b$ value significantly [20]. Similar result were reported by Sanchez Alanso et al. reported that the addition of wheat fibre increased the $b^{*}$ value significantly [18]. The colour of dietary fibre influences the fish fingers.

Effect of storage on the sensory properties of fish fingers: The fish fingers were evaluated for changes in sensory parameters during refrigerated storage $\left(4 \pm 1^{\circ} \mathrm{C}\right)$ for 15 Tokur days. The mean value of various sensory attributes i.e., appearance, flavour, juiciness, texture and overall acceptability during storage presented in Table 9. Sensorial scores showed that fish fingers were sensorially acceptable. Results showed that the sensory attributes of control group of $1^{\text {st }}$ day was significantly higher than the $15^{\text {th }}$ day of storage. The scores for the sensorial attributes for the fish fingers varied significantly $(\mathrm{P}<0.05)$ between storage days. As the storage days progressed, all sensory attributes followed a significant decreasing trend; however, in between treatment and control, sensory attributes were comparable throughout the storage period. The decrease in appearance scores might be due to the pigment and lipid oxidation resulting in non-enzymatic browning.

pH: The effect of storage on apple pomace powder

Table 7. Effect of refrigerated storage on the texture profile analysis of fish fingers.

\begin{tabular}{|c|c|c|c|c|}
\hline Parameters & Control & T1 & T2 & T3 \\
\hline Hardness (g) & $33.54 \pm 0.06^{\mathrm{a}}$ & $46.33 \pm 0.08^{b}$ & $48.7 \pm 0.01^{c}$ & $52.27 \pm 0.05^{d}$ \\
\hline Adhesiveness $(\mathrm{g} \times \mathrm{s})$ & $-0.054 \pm 0.003^{a}$ & $-0.035 \pm 0.001^{a}$ & $-0.033 \pm 0.001^{a}$ & $-0.030 \pm 0.00^{a}$ \\
\hline Springiness $(\mathrm{mm} / \mathrm{mm})$ & $0.016 \pm 0.002^{\mathrm{c}}$ & $0.014 \pm 0.02^{a}$ & $0.013 \pm 0.00^{a}$ & $0.011 \pm 0.00^{a}$ \\
\hline Cohesiveness $(\mathrm{mm} / \mathrm{mm})$ & $0.0072 \pm 0.00^{c}$ & $0.0070 \pm 0.00^{c}$ & $0.0066 \pm 0.00^{\mathrm{b}}$ & $0.0062 \pm 0.00^{a}$ \\
\hline Gumminess (g) & $25.05 \pm 0.02^{\mathrm{a}}$ & $33.92 \pm 0.00^{\mathrm{b}}$ & $34.51 \pm 0.00^{c}$ & $36.68 \pm 0.13^{d}$ \\
\hline Chewiness (g) & $13.63 \pm 0.012^{\mathrm{a}}$ & $17.76 \pm 0.09^{b}$ & $18.93 \pm 0.00^{c}$ & $19.34 \pm 0.09^{d}$ \\
\hline Resilience & $0.0066 \pm 0.00^{\mathrm{a}}$ & $0.0062 \pm 0.00^{\mathrm{a}}$ & $0.0055 \pm 0.00^{\mathrm{a}}$ & $0.0052 \pm 0.00^{\mathrm{a}}$ \\
\hline
\end{tabular}

All values are average of three determinations

Row-wise mean values bearing different superscripts (small) differ significantly $(p \leq 0.05)$

Control: Fish fingers with APP (0\%)

T1: Fish fingers with APP (2.5\%)

T2: Fish fingers with APP (4.5\%)

T3: Fish fingers with APP (6.5\%)

Table 8. Changes in colour parameters during refrigerated storage $\left(4 \pm 1^{\circ} \mathrm{C}\right)$ of fish fingers.

\begin{tabular}{|c|c|c|c|c|c|}
\hline \multirow{2}{*}{\multicolumn{2}{|c|}{ Colour parameters }} & \multicolumn{4}{|c|}{ Storage period (days) } \\
\hline & & \multirow{2}{*}{$\begin{array}{c}0 \\
41.81 \pm 0.59^{\mathrm{bc}}\end{array}$} & \multirow{2}{*}{$\begin{array}{c}\mathbf{5} \\
50.58 \pm 1.54^{\mathrm{bAB}}\end{array}$} & \multirow{2}{*}{$\begin{array}{c}10 \\
47.85 \pm 0.82^{\mathrm{bB}}\end{array}$} & \multirow{2}{*}{$\begin{array}{c}15 \\
52.22 \pm 1.54^{\mathrm{aA}}\end{array}$} \\
\hline \multirow{3}{*}{ C } & $L^{*}$ & & & & \\
\hline & $a^{*}$ & $6.3 \pm 0.93^{\mathrm{aA}}$ & $4.18 \pm 0.24^{\mathrm{aB}}$ & $4.7 \pm 0.28^{\mathrm{aB}}$ & $3.99 \pm 0.12^{\mathrm{aB}}$ \\
\hline & $b^{*}$ & $23.91 \pm 0.96^{\mathrm{aA}}$ & $20.52 \pm 0.10^{\mathrm{aB}}$ & $20.34 \pm 0.17^{\mathrm{aB}}$ & $20.04 \pm 0.10^{\mathrm{aB}}$ \\
\hline \multirow{3}{*}{ T1 } & $L^{*}$ & $48.44 \pm 1.83^{\mathrm{ac}}$ & $55.66 \pm 1.77^{\mathrm{aA}}$ & $51.34 \pm 0.37^{\mathrm{aBC}}$ & $54.06 \pm 1.82^{\mathrm{aAB}}$ \\
\hline & $a^{*}$ & $2.07 \pm 0.68^{\mathrm{bA}}$ & $0.72 \pm 0.32^{\mathrm{cB}}$ & $1.47 \pm 0.45^{\mathrm{CAB}}$ & $0.81 \pm 0.14^{\mathrm{cB}}$ \\
\hline & $b^{*}$ & $21.08 \pm 0.64^{\mathrm{bA}}$ & $18.91 \pm 0.61^{\mathrm{bC}}$ & $20.91 \pm 0.35^{\mathrm{aAB}}$ & $19.82 \pm 0.22^{\mathrm{aBC}}$ \\
\hline \multirow{3}{*}{ T2 } & $L^{*}$ & $46.29 \pm 0.34^{\mathrm{ac}}$ & $54.10 \pm 1.00^{\mathrm{abA}}$ & $50.78 \pm 0.69^{\mathrm{aA}}$ & $52.96 \pm 0.62^{\mathrm{aB}}$ \\
\hline & $a^{*}$ & $4.7 \pm 0.57^{\mathrm{aA}}$ & $3.99 \pm 0.12^{\mathrm{bB}}$ & $2.70 \pm 0.51^{\mathrm{bB}}$ & $2.54 \pm 0.29^{\mathrm{bB}}$ \\
\hline & $b^{*}$ & $20.67 \pm 0.60^{\mathrm{bA}}$ & $20.04 \pm 0.10^{\mathrm{aA}}$ & $20.51 \pm 0.43^{\mathrm{aA}}$ & $21.24 \pm 0.62^{\mathrm{aA}}$ \\
\hline \multirow{3}{*}{ T3 } & $L^{*}$ & $46.65 \pm 0.50^{\mathrm{ac}}$ & $51.70 \pm 0.97^{\mathrm{CAB}}$ & $49.99 \pm 1.8^{\mathrm{bB}}$ & $53.08 \pm 0.9^{d}$ \\
\hline & $a^{*}$ & $4.5 \pm 0.89^{a c}$ & $4.08 \pm 0.09^{\mathrm{bB}}$ & $2.37 \pm 0.79^{\mathrm{cB}}$ & $2.7 \pm 0.23^{\mathrm{cB}}$ \\
\hline & $b^{*}$ & $20.77 \pm 0.27^{\mathrm{aA}}$ & $20.33 \pm 0 . .^{25 \mathrm{aA}}$ & $20.58 \pm 0.29^{\mathrm{abA}}$ & $20.36 \pm 0.76^{\mathrm{bB}}$ \\
\hline
\end{tabular}

All values are average of three determinations $(n=3)$

Row-wise mean values bearing different superscripts (small) differ significantly ( $p \leq 0.05)$

Control(C): Fish fingers with APP (0\%)

T1: Fish fingers with APP (2.5\%)

T2: Fish fingers with APP (4.5\%)

T3: Fish fingers with APP (6.5\%) 
Table 9. Changes in sensory properties during refrigerated storage $\left(4 \pm 1^{\circ} \mathrm{C}\right)$ of fish fingers.

\begin{tabular}{|c|c|c|c|c|c|}
\hline \multirow{2}{*}{ Sensory properties } & \multirow{2}{*}{ Storage (days) } & \multicolumn{4}{|c|}{ Treatments } \\
\hline & & Control & T1 & T2 & T3 \\
\hline \multirow{4}{*}{ Appearance } & 0 & $4.68 \pm 0.00$ & $4.5 \pm 0.30$ & $3.86 \pm 0.33$ & $3.66 \pm 0.20$ \\
\hline & 5 & $4.33 \pm 0.28$ & $4.32 \pm 0.20$ & $3.76 \pm 0.24$ & $3.53 \pm 0.28$ \\
\hline & 10 & $3.76 \pm 0.24$ & $3.53 \pm 0.28$ & $3.43 \pm 0.35$ & $3.03 \pm 0.12$ \\
\hline & 15 & $3.43 \pm 0.35$ & $3.03 \pm 0.12$ & $2.6 \pm 0.32$ & $2.5 \pm 0.30$ \\
\hline \multirow{4}{*}{ Colour } & 0 & $4.51 \pm 0.23$ & $4.36 \pm 0.29$ & $3.98 \pm 0.25$ & $3.63 \pm 0.22$ \\
\hline & 5 & $4.48 \pm 0.25$ & $4.35 \pm 0.22$ & $3.86 \pm 0.22$ & $3.66 \pm 0.23$ \\
\hline & 10 & $3.86 \pm 0.22$ & $3.66 \pm 0.23$ & $3.46 \pm 0.38$ & $2.86 \pm 0.22$ \\
\hline & 15 & $3.46 \pm 0.30$ & $2.86 \pm 0.22$ & $2.5 \pm 0.12$ & $2.6 \pm 0.28$ \\
\hline \multirow{4}{*}{ Juiciness } & 0 & $4.30 \pm 0.31$ & $4.17 \pm 0.31$ & $3.98 \pm 0.25$ & $3.88 \pm 0.22$ \\
\hline & 5 & $4.42 \pm 0.25$ & $4.07 \pm 0.24$ & $3.93 \pm 0.16$ & $3.3 \pm 0.23$ \\
\hline & 10 & $3.93 \pm 0.16$ & $3.33 \pm 0.23$ & $3.13 \pm 0.22$ & $2.66 \pm 0.39$ \\
\hline & 15 & $3.13 \pm 0.22$ & $2.5 \pm 0.36$ & $2.66 \pm 0.39$ & $2.5 \pm 0.42$ \\
\hline \multirow{4}{*}{ Flavour } & 0 & $4.39 \pm 0.31$ & $4.39 \pm 0.36$ & $3.73 \pm 0.29$ & $3.57 \pm 0.25$ \\
\hline & 5 & $4.35 \pm 0.22$ & $4.20 \pm 0.22$ & $3.93 \pm 0.16$ & $3.3 \pm 0.24$ \\
\hline & 10 & $3.93 \pm 0.16$ & $3.33 \pm 0.24$ & $3.23 \pm 0.24$ & $2.66 \pm 0.23$ \\
\hline & 15 & $3.23 \pm 0.24$ & $2.6 \pm 0.27$ & $2.8 \pm 0.30$ & $2.4 \pm 0.39$ \\
\hline \multirow{4}{*}{ Texture } & 0 & $4.26 \pm 0.29$ & $4.20 \pm 0.35$ & $3.98 \pm 0.31$ & $3.57 \pm 0.25$ \\
\hline & 5 & $4.32 \pm 0.20$ & $4.01 \pm 0.31$ & $3.9 \pm 0.2$ & $3.26 \pm 0.24$ \\
\hline & 10 & $3.92 \pm 0.2$ & $3.2 \pm 0.20$ & $3.16 \pm 0.23$ & $2.7 \pm 0.24$ \\
\hline & 15 & $3.16 \pm 0.23$ & $2.7 \pm 0.24$ & $2.46 \pm 0.30$ & $2.4 \pm 0.29$ \\
\hline
\end{tabular}

Mean $\pm S D$ with different superscripts in a column wise (small alphabets) and row wise (capital alphabets) differ significantly ( $p<0.05$ ) and $n=21$ for each treatment.

Table 10. Effect of refrigerated storage on the $\mathrm{pH}$ content of fish fingers.

\begin{tabular}{|c|c|c|c|c|}
\hline \multirow{2}{*}{ Treatment } & \multicolumn{4}{|c|}{ Storage period (days) } \\
\cline { 2 - 5 } & $\mathbf{0}$ & $\mathbf{5}$ & $\mathbf{1 0}$ & $\mathbf{1 5}$ \\
\hline Control & $6.34 \pm 0.02^{\mathrm{aA}}$ & $6.27 \pm 0.01^{\mathrm{bA}}$ & $6.22 \pm 0.01^{\mathrm{CA}}$ & $6.20 \pm 0.01^{\mathrm{dA}}$ \\
\hline $\mathrm{T}_{1}$ & $6.30 \pm 0.01^{\mathrm{aB}}$ & $6.17 \pm 0.01^{\mathrm{bB}}$ & $6.10 \pm 0.01^{\mathrm{CB}}$ & $6.03 \pm 0.00^{\mathrm{dB}}$ \\
\hline $\mathrm{T}_{2}$ & $6.21 \pm 0.02^{\mathrm{aC}}$ & $6.13 \pm 0.00^{\mathrm{bC}}$ & $6.05 \pm 0.01^{\mathrm{CC}}$ & $6.07 \pm 0.01^{\mathrm{dC}}$ \\
\hline $\mathrm{T}_{3}$ & $6.14 \pm 0.01^{\mathrm{aD}}$ & $6.10 \pm 0.01^{\mathrm{bD}}$ & $6.02 \pm 0.01^{\mathrm{CD}}$ & $6.04 \pm 0.01^{\mathrm{dD}}$ \\
\hline
\end{tabular}

All values are average of fifteen determinations $(n=3)$

Row-wise mean values bearing different superscripts (Small) differ significantly ( $p$ $\leq 0.05)$

Control: Fish fingers with APP (0\%)

T1: Fish fingers with APP (2.5\%)

T2: Fish fingers with APP (4.5\%)

T3: Fish fingers with $A P P(6.5 \%)$

incorporated fish finger is depicted in Table 10. The effect of storage was obvious on the $\mathrm{pH}$ of fish fingers followed a decrease trend at progressive storage intervals. The $\mathrm{pH}$ followed a uniform trend up to $10^{\text {th }}$ day of storage, however beyond $10^{\text {th }}$ day of storage it didn't show much difference in T3 and $\mathrm{T} 4 \mathrm{pH}$ showed a slight increase. This decrease in $\mathrm{pH}$ during storage could be attributed to the availability of more readily carbohydrate molecule. Cadun et al. reported the same trend with the increase of apple fibre in fish patties $\mathrm{pH}$ values gets decreased [20].

Thiobarbituric acid (mg MA/kg): The Thiobarbituric acid (TBA) followed a significantly $(\mathrm{p} \leq 0.05)$ increasing trend during the entire storage period of 15 days. The increase was observed both in control and apple pomace powder treated products. However the rate of increase of TBA was higher in control and lowest in T3 (Table 11). The lower rate of increase in apple pomace powder treated products could be attributed to the presence of antioxidant substances in apple pomace powder. Kose et al. [27] reported the same trend of meat prepared
Table 11. Effect of refrigerated storage on the TBA content of fish fingers.

\begin{tabular}{|c|c|c|c|c|}
\hline \multirow{2}{*}{ Treatment } & \multicolumn{4}{|c|}{ Storage period (days) } \\
\cline { 2 - 5 } & $\mathbf{0}$ & $\mathbf{5}$ & $\mathbf{1 0}$ & 15 \\
\hline Control & $0.37 \pm 0.036^{\mathrm{bC}}$ & $0.54 \pm 0.145^{\mathrm{aB}}$ & $0.68 \pm 0.01^{\mathrm{aA}}$ & $0.60 \pm 0.02^{\mathrm{bA}}$ \\
\hline $\mathrm{T}_{1}$ & $0.39 \pm 0.043^{\mathrm{bD}}$ & $0.50 \pm 0.02^{\mathrm{aC}}$ & $0.59 \pm 0.02^{\mathrm{aB}}$ & $0.71 \pm 0.02^{\mathrm{abA}}$ \\
\hline $\mathrm{T}_{2}$ & $0.34 \pm 0.035^{\mathrm{bC}}$ & $0.45 \pm 0.03^{\mathrm{aB}}$ & $0.54 \pm 0.02^{\mathrm{aA}}$ & $0.64 \pm 0.02^{\mathrm{bA}}$ \\
\hline $\mathrm{T}_{3}$ & $0.32 \pm 0.04^{\mathrm{aC}}$ & $0.41 \pm 0.01^{\mathrm{aB}}$ & $0.49 \pm 0.04^{\mathrm{aA}}$ & $0.55 \pm 0.03^{\mathrm{aA}}$ \\
\hline
\end{tabular}

All values are average of three determinations

Row-wise mean values bearing different superscripts (small) differ significantly ( $p$ $\leq 0.05)$

Control: Fish fingers with APP (0\%)

T1: Fish fingers with $A P P(2.5 \%)$

T2: Fish fingers with APP (4.5\%)

T3: Fish fingers with $A P P(6.5 \%)$

from unwashed mince products, washed mince products and precooked mince products, respectively. Similar increase in the TBA was observed by Taskaya et al. in fish burger [28].

Microbiological quality of fish fingers during refrigerated storage $\left(4 \pm 1^{\circ} \mathrm{C}\right)$ : The microbiological properties of fish fingers (control and treatments packaged in LDPE) at refrigeration temperature $\left(4 \pm 1^{\circ} \mathrm{C}\right)$ for 15 days.

\section{Total plate count}

Mean values of total plate count (TPC) $(\log \mathrm{cfu} / \mathrm{g})$ of control and apple pomace powder incorporated fish fingers during refrigerated storage are presented in Table 12.

Microbial analysis revealed mean total plate count of control and treatments showed a significant $(\mathrm{p} \leq 0.05)$ increasing trend at progressive storage intervals with a slight difference although non-significant $(\mathrm{p} \geq 0.05)$ in total plate count of control and treatments during storage. Total plate count ranged from 1.52$3.22 \log \mathrm{cfu} / \mathrm{g}$ during refrigerated storage which was much 
Table 12. Influence of refrigerated storage $\left(4 \pm 1^{\circ} \mathrm{C}\right)$ on total plate count of fish fingers.

\begin{tabular}{|c|c|c|c|c|}
\hline \multirow{2}{*}{ Treatment } & \multicolumn{4}{|c|}{ Storage period (days) } \\
\cline { 2 - 5 } & $\mathbf{0}$ & $\mathbf{5}$ & $\mathbf{1 0}$ & $\mathbf{1 5}$ \\
\hline Control & $1.52^{\mathrm{aA}} \pm 0.05$ & $2.21^{\mathrm{bA}} \pm 0.04$ & $2.67^{\mathrm{cA}} \pm 0.05$ & $3.03^{\mathrm{dA}} \pm 0.05$ \\
\hline $\mathrm{T}_{1}$ & $1.42^{\mathrm{aAB}} \pm 0.05$ & $2.17^{\mathrm{bAB}} \pm 0.04$ & $2.49^{\mathrm{cB}} \pm 0.04$ & $2.87^{\mathrm{dA}} \pm 0.04$ \\
\hline $\mathrm{T}_{2}$ & $1.37^{\mathrm{aBC}} \pm 0.05$ & $2.09^{\mathrm{bBC}} \pm 0.04$ & $2.34^{\mathrm{cB}} \pm 0.04$ & $2.57^{\mathrm{dB}} \pm 0.04$ \\
\hline $\mathrm{T}_{3}$ & $1.28^{\mathrm{aC}} \pm 0.02$ & $2.00^{\mathrm{bC}} \pm 0.04$ & $2.18^{\mathrm{cB}} \pm 0.04$ & $2.32^{\mathrm{dC}} \pm 0.02$ \\
\hline
\end{tabular}

All values are average of three determinations $(n=3)$

Row-wise mean values bearing different superscripts (small) differ significantly ( $p$ $\leq 0.05$ )

Column-wise mean values bearing different superscripts (capital) differ significantly $(p \leq 0.05)$

Control: Fish fingers with APP (0\%)

T1: Fish fingers with APP (2.5\%)

T2: Fish fingers with $A P P(4.5 \%)$

T3: Fish fingers with APP (6.5\%)

below the incipient spoilage level of $7.0 \log _{10} \mathrm{cfu} / \mathrm{g}$ [29]. This could be due to salt, various spices and condiments added to the fish fingers which possess strong antimicrobial activities. Lower total plate counts of apple pomace powder based fish fingers might be due to their antimicrobial effect and lower $\mathrm{pH}$ of treated groups than control which resulted in inhibition of microbial growth. The antimicrobial activity might also be attributed to the bioactive compounds present in fibre especially polyphenols and terpenes. The same increase of bacterial count was observed by various researchers in different fish products stored in refrigerated condition [28,30,31]. Praneetha et al. observed the same trend during the storage of fish fingers at refrigerated condition [32]. Reddy and Rao observed a similar increase of total plate counts while studying the effect of binders and precooked meat on the quality of chicken loaves at refrigeration temperature [33]. Viuda-Martos et al. reported that the incorporation of orange dietary fibre in bologna sausage stored in vacuum packaging showed lower TPC than control [34].

\section{Yeast and mould count}

Yeast and mould count (log cfu/g) of control and apple pomace powder incorporated fish fingers during refrigerated storage are presented in Table 13.

Table 13. Influence of refrigerated storage $\left(4 \pm 1^{\circ} \mathrm{C}\right)$ on yeast and mould count of fish fingers.

\begin{tabular}{|c|c|c|c|c|}
\hline \multirow{2}{*}{ Treatment } & \multicolumn{4}{|c|}{ Storage period (days) } \\
\cline { 2 - 5 } & $\mathbf{0}$ & $\mathbf{5}$ & $\mathbf{1 0}$ & $\mathbf{1 5}$ \\
\hline Control & $\mathrm{ND}$ & $\mathrm{ND}$ & $\mathrm{ND}$ & $1.61^{\mathrm{aA}} \pm 0.10$ \\
\hline $\mathrm{T}_{1}$ & $\mathrm{ND}$ & $\mathrm{ND}$ & $\mathrm{ND}$ & $0.83^{\mathrm{aB}} \pm 0.05$ \\
\hline $\mathrm{T}_{2}$ & $\mathrm{ND}$ & $\mathrm{ND}$ & $\mathrm{ND}$ & $0.65^{\mathrm{aBC}} \pm 0.04$ \\
\hline $\mathrm{T}_{3}$ & $\mathrm{ND}$ & $\mathrm{ND}$ & $\mathrm{ND}$ & $0.36^{\mathrm{aC}} \pm 0.04$ \\
\hline
\end{tabular}

All values are average of three determinations $(n=3)$

Row-wise mean values bearing different superscripts (small) differ significantly (p 0.05)

Column -wise mean values bearing different superscripts (capital) differ significantly $(p \leq 0.05)$

Control: Fish fingers with APP (0\%)

T1: Fish fingers with APP (2.5\%)

T2: Fish fingers with APP (4.5\%)

T3: Fish fingers with APP (6.5\%)
Yeast and mould count were not detected up to the $10^{\text {th }}$ day of storage in control as well as apple pomace powder treated fish fingers. Yeast and mould counts enumerated were significantly $(\mathrm{p} \leq 0.05)$ higher for control than for all the treatments. Among treatments, the difference in yeast and mould count was non-significant $(\mathrm{p} \geq 0.05)$ Yeast and mould count were not detected on 0 and 10th day of storage. Afterwards there was a significant increase $(p \leq 0.05)$ in control as well as treatments from $15^{\text {th }}$ day of storage. The absence of yeast and mould in the early period of storage could be due to high heat treatment, good hygienic practices and absence of post cooking contamination. Addition of salt, spices and condiments might also have contributed to low yeast and mould count in control as well as apple pomace powder extended fish fingers. Many studies have determined the combined effect of adding orange dietary fibre and oregano essential oil on microbial growth in meat products [19].

\section{Conclusion}

The results of physico-chemical analysis revealed that the product $\mathrm{pH}$ decreased significantly $(\mathrm{p} \leq 0.05)$ with the addition of apple pomace powder. Cooking yield and emulsion stability increased significantly $(\mathrm{p} \leq 0.05)$ with the addition of apple pomace powder. Proximate composition revealed that moisture content, crude protein, crude fat and ash content of fish fingers decreased significantly ( $\mathrm{p} \leq 0.05)$ with the increasing levels of apple pomace powder. Crude fiber content of products increased significantly $(\mathrm{p} \leq 0.05)$ with the addition of apple pomace powder.

\section{Acknowledgement}

The group is thankful to Department of Food Technology, IUST Awantipora, J \& K, India for the support of this research work.

\section{Conflict of interest}

The authors do not have any conflict of interest.

\section{References}

1. Evangelos SL, Aggelousis G, Alexakis A. Metal and proximate composition of the edible portion of 11 freshwater fish species. J Food Compost Anal. 1989;2:371-81.

2. Nettleton JA. Seafood nutrition in the 1990. Seafood Nutrition in the 1990s: Issues for the consumer. In Bligh, E. G. (ed). Seafood Science and technology. Fishing news Books. London. 1990;32-9.

3. Eastwood MA. The physiological effect of dietary fibre: an update. Annual review of Nutrition. 1992;12(1):19-35.

4. Johnson IT, Southgate DAT. Dietary fibre and related substances. Springer. 2013.

5. Bravo L, Saura- Calixto F, Goni I. Effects of dietary fibre and tannins from apple pulp on the composition of faeces in rats. Br J Nutr. 1992;67(3):463-73. 
6. Tokur B, Ozkütük S, Atici E, et al. Chemical and sensory quality changes of fish fingers, made from mirror carp (Cyprinus carpio L., 1758), during frozen storage (-18 $\left.{ }^{\circ} \mathrm{C}\right)$. Food Chem. 2006;99(2):335-41.

7. Mertens D. AOAC official method 975.03. Metal in Plants and Pet Foods. Official Methods of Analysis. 18th edn. Horwitz W and GW Latimer. 2005;3-4.

8. Witte VC, Krause GF, Bailey ME. A new extraction method for determining 2 thiobarbituric acid values of pork and beef during storage. J Food Sci. 1970;35(5):582-5.

9. Bourne MC, Kenny JF, Barnard J. Computer assisted readout of data from texture profile analysis curves. Journal of Texture Studies. 1978;9(4):481-94.

10. Lakshman M, Devivaraprasad Reddy A, Khuntia BK, et al. Qualitative and quantitative changes of fried fish steaks and fish steak curry of catla (Catla catla) during frozen storage. International Food Research Journal. 2015;22(5):2057-67.

11. Weiss SJ, Regiani S. Neutrophils degrade subendothelial matrices in the presence of alpha-1-proteinase inhibitor. Cooperative use of lysosomal proteinases and oxygen metabolites. The Journal of clinical investigation. 1984;73(5):1297-303.

12. Carr GJ, Gorelick NJ. Statistical design and analysis of mutation studies in transgenic mice. Environ Mol Mutagen.1995;25(3):246-55.

13. Lavent IZCI, Bilgin S. Sensory acceptability and fatty acid profile of fish crackers made from Carassius gibelio. Food Science and Technology. 2015;35(4):643-46.

14. Verma AK, Sharma BD, Banerjee R. Effect of sodium chloride replacement and apple pulp inclusion on the physico-chemical, textural and sensory properties of low fat chicken nuggets. LWT-Food Science and Technology. 2010;43(4):715-9.

15. Huda N, Shen YH, Huey YL, et al. Ingredients, proximate composition, colour and textural properties of commercial Malaysian Fish Balls. Pakistan Journal of Nutrition. 2010;9(12):1183-6.

16. Gracia ML, Dominguez R, Galvez MD, et al. Utilization of cereal and fruit fibres in low fat dry fermented sausages. Meat Sci.2002;60:227-36.

17. Mendoza E, Garcia ML, Casas C, et al. Inulin as fat substitute in low fat, dry fermented sausages. Meat Sci. 2001;57(4):387-93.

18. Sánchez-Alonso I, Jiménez-Escrig A, Saura-Calixto F, et al. Effect of grape antioxidant dietary fibre on the prevention of lipid oxidation in minced fish: evaluation by different methodologies. Food Chem. 2007;101(1):372-8.

19. Fernández-López J, Fernández-Ginés JM, Aleson-Carbonell $\mathrm{L}$, et al. Application of functional citrus by-products to meat products. Trends in Food Science \& Technology. 2004;15(34):176-85.
20. Cadun A, İaklı S, Kışla D, et al. Effect of Fibres on the Quality of Fish Patties Stored at $\left(0-4^{\circ} \mathrm{C}\right)$. J Food Health Sci. 2015; 1(4): 211-219.

21. Verma AK, Rajkumar V, Banerjee R, et al. Guava (Psidium guajava L.) powder as an antioxidant dietary fibre in sheep meat nuggets. Asian-Australas J Anim Sci. 2013;26(6):88695.

22. Choi YS, Choi JH, Han DJ, et al. Characteristics of low-fat meat emulsion systems with pork fat replaced by vegetable oils and rice bran fibre. Meat Sci. 2009;82(2):266-71.

23. Besbes S, Attia H, Deroanne C, et al. Partial replacement of meat by pea fibre and wheat fibre: effect on the chemical composition, cooking characteristics and sensory properties of beef burgers. Journal of Food Quality. 2008;31(4):480-9.

24. Mitsyk VE, Mikhailovskii VS. Minced meat semimanufactured products incorporating pea-meal and sunflower seed meal protein. Tovarovedenie. 1981;14:44-6.

25. Kilinc B, Cakli S, Dincer T, et al. Effects of phosphates treatment on the quality of frozen $\square$ thawed fish species. Journal of Muscle Foods. 2009;20(4):377-91.

26. Lin KW, Lin HY. Quality Characteristics of Chinese style Meatball Containing Bacterial Cellulose (Nata). J Food Sci. 2004; 69(3).

27. Köse S, Balaban MO, Boran M, et al. The effect of mincing method on the quality of refrigerated whiting burgers. Int J Food Sci Technol. 2009; 44(8): 1649-1660.

28. Taşkaya L, Cakli S, Kişla D, et al. Quality changes of fish burger from rainbow trout during refrigerated storage. Journal of Fisheries and Aquatic Sciences. 2003;20:147-54.

29. Garland JL. Analytical approaches to the characterization of samples of microbial communities using patterns of potential C source utilization. Soil Biology and Biochemistry. 1996;28(2):213-21.

30. Cakli S, Kilinc B, Cadun A, et al. Quality differences of whole ungutted sea bream (Sparus aurata) and sea bass (Dicentrarchus labrax) while stored in ice. Food Control. 2007;18(5):391-7.

31. Baygar T, Erkan N, Mol S, et al. Determination of the shelf-life of trout (Oncorhynchus mykiss) raw meatball that packed under modified atmosphere. Pakistan Journal of Nutrition. 2008;7(3):412-7.

32. Praneetha SS, Dhanapal K, Reddy GVS, et al. Development of fish finger from rohu (labeo rohita) and its quality evaluation during refrigerated storage condition. International Journal of Science, Environment and Technology. 2015;4:1457-68.

33. Rao CV, Desai D, Kaul B, et al. Effect of caffeic acid esters on carcinogen-induced mutagenicity and human colon adenocarcinoma cell growth. Chemico-Biological Interactions. 1992;84(3):277-90. 
34. Viuda-Martos M, Ruiz-Navajas Y, Fernández-López J, et al. Effect of orange dietary fibre, oregano essential oil and packaging conditions on shelf-life of bologna sausages. Food Control. 2010;21(4): 436-43.

\section{*Correspondence to:}

Murtaza Gani

Department of Food Technology

IUST Awantipora

Kashmir

India

9622741588

E-mail: kmurtazakmg@gmail.com 